\title{
Application of Mind-Body Practice: Yoga for Reducing Long Pain Primary Dysmenorrhea
}

\author{
$1^{\text {st }}$ Mar atun Ulaa \\ Lecturer of Medical Laboratory \\ Technology \\ STIKes Muhammadiyah Palembang \\ Palembang, Indonesia \\ maratunulaa@gmail.com \\ $4^{\text {th }}$ Windy Astuti Cahya Ningrum \\ Lecturer of Medical Laboratory \\ Technology \\ STIKes Muhammadiyah Palembang \\ Palembang, Indonesia \\ $7^{\text {th }}$ Annisa Rahmania \\ Lecturer of Medical Laboratory \\ Technology \\ STIKes Muhammadiyah Palembang \\ Palembang, Indonesia
}

\author{
$2^{\text {nd }}$ Renny Triwijayanti \\ Lecturer of Medical Laboratory \\ Technology \\ STIKes Muhammadiyah Palembang \\ Palembang, Indonesia \\ $5^{\text {th }}$ Trilia \\ Lecturer of Medical Laboratory \\ Technology \\ STIKes Muhammadiyah Palembang \\ Palembang, Indonesia
}

\author{
$3^{\text {rd }}$ Maya Fadlilah \\ Lecturer of Medical Laboratory \\ Technology \\ STIKes Muhammadiyah Palembang \\ Palembang, Indonesia \\ $6^{\text {th }}$ Inne Yelisni \\ Lecturer of Medical Laboratory \\ Technology \\ STIKes Muhammadiyah Palembang \\ Palembang, Indonesia
}

\begin{abstract}
Dysmenorrhea is a common complaint in young women, characterized by pain. Dysmenorrhea pain has a significant impact on womens lives, such as limitations in daily activities. Primary dysmenorrhea can be treated using yoga and self tapping. Objective: understanding effectiveness on use of mind-body practice: yoga towards changing long pain of primary dysmenorrheal. Method: Study was conducted by quasi experiment with nonequivalent pretest-posttest control group design. Study was conducted on November 2016 until Februari 2017 in SMK "X" and SMK "Y" Klaten. Sample of study amounted 88 respondent divided on 47 respondent on experimental group and 41 respondent as control group. The experimental group was given a yoga intervention, control group was given self tapping. Measuring tool using Numerical Rating Scale (NRS). Data analysis using t-test for independent sample, Mann-Whitney test and Wilcoxon. Result: Statistically yoga and self tapping were equally effective in reducing the long pain of primary dysmenorrheal with $p$ values of 0.000 and 0.012 respectively. Clinically yoga is more effective in reducing the long pain of primary dysmenorrhea with mean 1,49 compared with self tapping 0,46. Conclusion: Yoga intervention effective on reduction long pain of primary dysmenorrhea.
\end{abstract}

Keywords-Application, Mind-Body, Yoga, Dysmenorrhea

\section{INTRODUCTION}

Dysmenorrhea is a common complaint and often occurs on girls adolescent and women in reproductive age with marked cramps in lower abdominal area during menstruation. Prymary dismenorrhe occured without pathological conditions in female reproductive organs. The heaviest duration of pain usually occured on 48 to 72 hours in a single menstrual cycle $[1,2,3]$.
Pain period have a significant impact on women's lives. The highest prevalence of primary dysmenorrhea occured on girls adolescent, ranging from $20 \%-90 \%$, sixty percent occured on adolescents aged 12-17 years old and peaks at the age of 20-24 years. Based on research conducted by Rodrigues (2011), 62,8 \% of respondents experience menstrual pain and $65.7 \%$ experience limitations in daily activities due to dysmenorrheal [4]. Prevalence of limitations in daily activities was influenced by the intensity and duration of pain. A similar study was conducted in Canberra and Western Australia showed an estimated prevalence of adolescents absent from school due to menstrual symptoms of $80 \%-94 \%[1,3,5,6,7]$.

The prevalence of primary dysmenorrhea in Indonesia is estimated to be $55 \%$ in women of reproductive age [8]. Based on the results of research Mardiyah et al (2015) conducted on adolescents in Madrasah Aliyah Negeri (MAN) 1 Semarang result $65.2 \%$ of respondents experiencing dysmenorrhea [9]. Wijayanti (2008) conducted research on the students SMA Muhammadiyah 1 Yogyakarta63.6\% of the students had primary dysmenorrhea [10].

Management of primary dysmenorrhea can be done by pharmacological and nonpharmacological approaches. Nonpharmacologic approaches have been used with some degree of success. Based on data from the 2007 National Health Interview Survey (NHIS), forty percent of adults use complementary therapies such as acupuncture, deep breathing exercises, massage therapy, meditation, naturopathy and yoga $[11,12,13]$.

Yoga is a mind-body practice derived from ancient Indian philosophy, consisting of physical posture (asana), breathing exercises (pranayama), and meditation 
(dhyana), which integrate the balance of body and mind in harmony [14]. In addition, therapy that can be used to overcome the pain is self tapping. Self tapping is a self tapping touch. Tapping touch is a thorough maintenance technique using a rhythmic touch. Gentle massage helps to reduce the tension in the body and mind and increase feelings of prosperity and positive thoughts [15].

Based on preliminary study was conducted in SMK "A" Pedan Klaten, girls have experienced dysmenorrhea pain during menstruation on 1-3 days of 200 students (59\%). Sixty point five percent feel annoyed at the time of learning and $56 \%$ can not learn effectively.

Based on the above description, researchers are interested to know the difference between the use of yoga and self tapping on changes in the long pain of primary dysmenorrhea. This is supported by the absence of a study comparing yoga and self tapping interventions to address long pain of primary dysmenorrhea.

\section{METHOD}

Study was conducted by quasi experiment with nonequivalent pretest-posttest control group design, by dividing the respondents into experimental groups (SMK "X") and control groups (SMK "Y"). In the experimental group given yoga intervention and control group given self tapping intervention. Pain measured by Numerical Rating Scale (NRS) with validity value $r>0,86$ and reliability based on value of test-retest $r=0,96$ and $r=0,95$.

This research was conducted on 22 November 2016 until 27 February 2017, with total population of 641 students aged 14-18 years, with keriteria inclusion have got menstruation, experiencing primary dysmenorrhea, menstrual cycle regularly in the last 2 months, coming from the Javanese tribe and willing to be a respondent. While the criteria for the exclusion are consuming drugs or drink pain relievers, consuming alcohol, body time index $<18.5$, experiencing anxiety with score $\geq 55$ and performing at least 2 Times of the week (including yoga, classical ballet, and athletics).

The number of samples in this study was calculated using the formula Lemeshow, et al (1997), the results obtained sample of 45 people, to anticipate the dropout rate plus $10 \%$ of the total sample, and the samples in this study of 50 people for each group (experimental and control), With a total sample of 100 people taken using simple random sampling technique by way of drawing. Fifty respondents in the experimental group who participated in the study, only 47 respondents completed the study according to the study protocol, 3 respondents drop out. While in the control group of 50 respondents who participated in the study, only 41 respondents completed the study according to the study protocol, 9 respondents drop out.

This research was conducted after obtaining the approval or feasibility of ethical research from the Ethics Commission in Faculty of Medicine, Gadjah Mada University with reference number: KE/FK/1261/EC/2016 November 21, 2016. The researcher was assisted by two research assistants, who had previously done a perception equation on how to disseminate and guided the screening questionnaire, State Trait Anxiety Inventory Form Y (STAI-Y), Numerical Rating Scale (NRS).

The researcher also uses 1 person facilitator and 6 facilitator assistants, research facilitator is yoga instructor from Yoga First Klaten certified studio, licensed yoga alliance and has experience of yoga teaching for more than 5 years. Yoga facilitator assisted by three assistant facilitator of First Yoga studio Klaten certified and have at least 2 years of yoga experience. As for self tapping is taught by a research assistant who has been trained to teach self tappping movements. The self tapping facilitator will be assisted by 3 assistants who have previously performed apperception related to the procedure and research implementation.

Implementation of data collection begins with screening using questionnaires and measurements of height and weight to all prospective respondents who previously had been given explanation of the research. Prospective respondents who fulfilled inclusion and exclusion criteria were taken 100 people (each school 50 people). Further explaining the research process and informing consent, and distributing NRS instruments (pretest) and explaining how to fill it.

The collection of pretest data was done by asking respondents to fill in NRS instruments every day during menstruation. The first pain intensity measurements were performed for up to 10 hours after the first day's menstruation, for subsequent measurements taken at the same time as the first day of measurement. NRS instrument filling is monitored by researchers and research assistants either directly or through social media such as WhatsApp group (WA group), BlackBerry Messenger group (BBM group) or Short Message Service (SMS). After menstruation is complete respondents are asked to collect back NRS instruments that have been filled to researchers or research assistant.

Subsequently given health education, the respondents were divided into two groups (experimental group and control group). Experimental group taught yoga and control group taught self tapping. The facilitator explains the general guidelines of yoga practice or self tapping, followed by demonstration of yoga or self tapping procedures assisted by assistant facilitators followed by all respondents. After the demonstration the respondents were divided into 4 smaller groups (consisting of 12-13 people), each group was guided by the facilitator's assistant until the respondent was able to intervene properly using the teach-back technique (redemonstration) and evaluated using the observation sheet in the form check list.

Furthermore, researchers will distribute NRS (posttest) instruments, monitoring sheets and health education evaluation questionnaires after intervention. Respondents were asked to complete NRS instruments and monitoring sheets daily as long as the respondent had menstruation. Measuring the intensity of pain, TD and N on the first day was performed maximum of 10 hours after the respondent intervened (yoga intervention was done for 30 minutes each session while self tapping was done for 
20 minutes each session). For the next measurement is done at the same time with the first day measurement time.

Researchers and research assistants monitor the implementation of NRS instrument intervention and completeness as well as monitoring sheets directly or indirectly through social media, as described previously. After the menstruation is complete the respondent is asked to reassemble the NRS (posttest) instrument and the completed monitoring sheet completely. Data analysis was performed using t-test for independent sample, MannWhitney and Wilcoxon test.

\section{RESEARCH RESULT}

After analyzing data can be presented characteristics and homogeneity of respondents by age, age of menarche, Body Mass Index (BMI), long periods and anxiety in Table 1 below:

TABLE 1. CHARACTERISTICS OF RESEARCH AND HOMOGENEITY OF EXPERIMENTAL AND CONTROL GROUP IN SMK "X" AND SMK "Y" KLATEN 2017.

\begin{tabular}{lccc}
\hline \multirow{2}{*}{ Characteristics } & \multicolumn{2}{c}{ Group } & \\
\cline { 2 - 3 } & Experiment $(\mathrm{n}=50)$ & Control $(\mathrm{n}=50)$ & \\
\cline { 2 - 3 } & Mean $\pm \mathrm{SD}$ & Mean \pm SD & \\
\hline Age of respondents (years) & $15,14 \pm 0,49$ & $15,20 \pm 0,53$ & 0,50 \\
Age of Menarche (years) & $12,70 \pm 0,76$ & $12,54 \pm 0,71$ & 0,49 \\
Body Mass Index (BMI) $\left(\mathrm{kg} / \mathrm{m}^{2}\right)$ & $20,50 \pm 3,13$ & $20,16 \pm 2,69$ & 0,73 \\
Long Menstruation (day) & $5,90 \pm 1,11$ & $6,28 \pm 1,13$ & 0,69 \\
Anxiety STAI-Y1 & $44,28 \pm 7,60$ & $43,82 \pm 6,24$ & 0,24 \\
Anxiety STAI-Y2 & $44,24 \pm 6,01$ & $42,78 \pm 7,08$ & 0,20 \\
\hline
\end{tabular}

$\mathrm{P}$ value was obtained based on t-test for independent sample

Table 1 shows the respondents in this study homogeneous with the overall $p$ value greater than 0,05 based on the homogeneity test result using t-test for independent TABLE 2. DESCRIPTION OF HOMOGENEITY OF DATA ON LONG PAIN PRIOR TO INTERVENTION OF EXPERIMENTAL AND CONTROL GROUP IN SMK "X" AND SMK "Y" KLATEN 2017.

\begin{tabular}{|c|c|c|c|c|c|c|c|}
\hline \multirow[b]{2}{*}{ Variable } & \multicolumn{3}{|c|}{ Experiment } & \multicolumn{3}{|c|}{ Control } & \multirow[b]{2}{*}{$P^{*}$} \\
\hline & $\mathrm{n}$ & $\begin{array}{c}\text { Median } \\
\text { (min-max) }\end{array}$ & Mean \pm SD & $\mathrm{n}$ & $\begin{array}{c}\text { Median } \\
\text { (min-max) }\end{array}$ & Mean \pm SD & \\
\hline Pain Intensity & 50 & $3,00(1-8)$ & $3,54 \pm 1,681$ & 50 & $3,00(1-7)$ & $3,32 \pm 1,301$ & 0,574 \\
\hline
\end{tabular}

$*$ P values were obtained based on the Mann-Whitney test Based on homogeneity test results in table 2 above shows that the characteristics of long pain before the intervention between the experimental and control groups is homogeneous, with a value of $\mathrm{p} \geq 0.05$.

TABLE 3. AN ILLUSTRATION OF THE LONG PAIN OF EXPERIMENTAL AND CONTROL GROUP BEFORE AND AFTER INTERVENTION IN SMK "X" AND SMK "Y" KLATEN 2017.

\begin{tabular}{|l|c|c|c|c|c|c|c|c|}
\hline \multirow{2}{*}{ Group } & \multicolumn{4}{|c|}{ Pretest } & \multicolumn{3}{c|}{ Posttest } & \multicolumn{2}{c|}{$\begin{array}{c}\text { Mean } \\
\text { Difference }\end{array}$} & $P^{*}$ \\
\cline { 2 - 10 } & $\mathrm{n}$ & $\begin{array}{c}\text { Median } \\
\text { (min-max) }\end{array}$ & Mean \pm SD & $\mathrm{n}$ & $\begin{array}{c}\text { Median } \\
(\text { min-max })\end{array}$ & Mean \pm SD & & \\
\hline Experiment & 47 & $3,00(1-8)$ & $3,53 \pm 1,718$ & 47 & $2,00(0-6)$ & $2,04 \pm 1,574$ & 1,49 & 0,000 \\
Control & 41 & $3,00(1-6)$ & $3,12 \pm 1,166$ & 41 & $3,00(0-5)$ & $2,66 \pm 1,109$ & 0,46 & 0,120 \\
\hline
\end{tabular}

* $\mathrm{P}$ values are obtained based on the Wilcoxon test

In Table 3 above shows that statistically there was a significant decrease in long pain before and after intervention only in the experimental groups, wheareas the control group did not have significant decrease in long pain. Clinically, the mean difference of decrease in long pain before and after intervention of the experimental group was higher than control group.

\section{DISCUSSION}

Characteristic of respondent included age, menarche age, body mass index (BMI), menstrual period and anxiety of respondents. Based on characteristics of respondents
The change of long pain before and after intervention in experiment and control group, as shown in table 3 below:

sample. Homogeneity test on long pain between experimental group and control group, as shown in table 2: 
years. According to Kolhe (2016), age of menarche affects primary dysmenorrhea, this opinion is in line with Perry et al (2014) Which states that severe dysmenorrhea is always associated with early menarche $[18,19]$. Women who have menarche less than 12 years have a risk to experience pain during menstruation $[20,21]$.

Body Mass Index (BMI) is a measure that compares the weight (in kilograms) with the square of the height (in meters). Body Mass Index between the experimental group and control group in this study was homogeneous $(p=0.73)$, with mean $\geq 18.5$. According to Osayande et al (2014) a low Body Mass Index is a risk factor for dysmenorrhea [21]. According toPerry et al (2014) The average duration of menstrual blood discharge is 5 days, with a range of 3-6 days [19]. The mean duration of menstruation between the experimental and control groups in this study was 5.9 and 6.28 days. According to ACOG (2015), most women experience menstruation for 2-7 days [22].

In this study, the instant anxiety score (state anxiety) as measured by STAI Y-1 instrument between the experimental group and the homogeneous control group, as well as the trait anxiety measured using the STAIY-2 instrument having a homogeneous score. Respondents in this study did not experience the momentary anxiety and basic anxiety. Anxiety has a reciprocal relationship with pain perception. When anxiety increases then the perception of pain will increase, vice versa if the perception of pain increases then anxiety will increase. People who have stable emotions will more easily tolerate pain than people who have unstable emotions [16]. Based on the results of research Dhayita (2011) there is a significant relationship between emotional stability before menstruation with the emergence of dysmenorrhea [23]. Wijayanti (2008) Examined the relationship of stress with the incidence of primary dysmenorrhea, the results statistically there is a significant relationship between stress with the incidence of primary dysmenorrhea in adolescents [10]. According to Kolhe (2016) psychosocial factors play a role in the perception and severity of pain [18].

\subsection{Differences long pain of primary dysmenorrhea before and after yoga.}

The results of this study were statistically significant differences in the long pain of primary dysmenorrhea before and after yoga (table 3 ). The results of this study confirm previous research conducted by Rakhshaee (2011) That there was a significant difference in intensity and duration of pain before and after intervention in the yoga group [24]. Siahaan (2011) also conducted a study that aims to determine the influence of yoga on dysmenorrhea level, the result is influence of yoga on dysmenorrhea [25]. Based on research Rani et al (2011) yoga nidra can also reduce the intensity of pain, gastrointestinal symptoms, cardiovascular symptoms and reduce symptoms of urogenital significantly [26].

1.2 Differences long pain of primary dysmenorrhea before and after self-tapping.

In this study the control group was given self tapping intervention, the result statistically not significant difference of long pain before and after self tapping (table 3 ). This study are statistically inconsistent with research conducted by Akbar (2015), the result there is a significant difference of pain intensity primary dysmenorrhea before and after self tapping [27].

1.3 Differences long pain of primary dysmenorrhea experimental group who performed yoga with a control group that performed self-tapping.

The results of this study statistically showed decrease in long pain before and after intervention only in yoga intervention. Clinically, the mean difference of decrease in long pain before and after yoga intervention in the experimental group were higher than the control group (Table 3). So the conclusions of interpretation of long pain in the experimental group were statistically and clinically compatible, whereas in the control group were statistically and clinically incompatible.

The results of this study confirm previous research conducted by Sakuma et al (2012), the results were statistically significant differences in pain intensity before and after intervention between yoga groups compared with the control group. While the clinical average decrease in intensity of menstrual pain group given by intervention home-based simple yoga is higher than the control group [14]. Manurung (2015) also conducted a study on the effectiveness of yoga on dysmenorrhea pain in adolescents, the results were statistically significant differences in pain intensity before and after intervention in the experimental group taught yoga compared to the untreated control group [28].

\section{CONCLUSION}

Yoga intervention effective on reduction long pain of primary dysmenorrhea.

\section{REFERENCES}

[1] Zhu X, Proctor M, Bensoussan A, Wu E and Smith CA. 2008. Chinese Herbal Medicine for Primary Dysmenorrhoea (review). The Cochrane Library, Issue 2.

[2] Fedorowicz Z, Nasser M, Jagannath VA, Beaman JH, Ejaz K and van Zuuren EJ. 2012. Beta2 Adrenoceptor Agonists for Dysmenorrhoea (review). The Cochrane Library. Issue 5.

[3] Sugumar R, Krishnaiah, Charnnavera GS and Mruthyunjaya S. 2013.Comparison of the Pattern, Efficacy, and Tolerability of Self-medicated Drugs in Primary Dysmenorrhea: A Questionnaire Based Survey. Indian J Pharmacol; 45(2): 180 183

[4] Rodrigues AC, Gala S, Neves A, Pinto C, Meirelles C, Frutuoso $\mathrm{C}$ and Vitor ME. 2011. Dismenorreia Em Adolescentes E Jovens Adultas Prevalencia, factores Associados e Limitacoes na Vida Diaria. Acta Med Port; 24 (S2): 383-392.

[5] Azurah AGN, Sanci L, Moore E \& Gover S, 2013. The Quality of Life of Adolescents with Menstrual Problem.J Pediatr Adolesc Gynecol; 26; 102-108

[6] Dmitrovic R, Kunselman AR and Legro RS. 2013. Sildenafil Citrate in the Treatment of Pain in Primary Dysmenorrhea a Randomized Controlled Trial. Human Reproduction, Vol.28, No.11 pp. 2958-2965

[7] Azima S, Bakhshayesh H, Kaviani M, Abbasnia K and Sayadi M. 2015.Comparison of the Effect of Massage Therapy and Isometric Exercises on Primary Dysmenorrhea A randomized Controlled Clinical Trial. J Pediatr Adolesc Gynecol; xxx; 1-6.

[8] Proverawati A dan Misaroh S. 2009.Menarche Menstruasi Pertama Penuh Makna.Yogyakarta: Nuha Medika 
[9] Mardhiyah U, Rosidi A dan Purwanti IA. 2015. Pola Dysmenorrhea Primer pada Remaja di MAN 1 Semarang. The $2^{\text {nd }}$ University Reasearch Coloquium.

[10] Wijayanti E. 2008. Hubungan Stres dengan kejadian Dysmenorrhea Primer pada Remaja di SMA Muhammadiyah 1 Yogyakarta.Skripsi. Universitas Gadjah Mada.

[11] Johnson PJ, Ward A, Knutson L, and Sendelbach S. 2012.Personal Use of Complementary and Alternative Medicine (CAM) by U.S. Health Care Worker.HRS: Health Services Research, Part I, 47:1

[12] Cramer H, Lauche Rand Dobos G, 2014. Characteristics of Randomized Controlled Trials of Yoga: a Bibliometric Analysis. Complementery and Alternative Medicine, 14; 328

[13] Aziato L, Dedey F and Dlegg-Lamptey JNA. 2015. Dysmenorrhea Management and Coping among Students in Ghana: A Qualitative Exploration. J Pediatr Adolesc Gynecol. 28; 163-169

[14] Sakuma Y, Otomaru AS, Ishida S, Kanoya Y, Arakawa C, Mochizuki Y, Seiishi Y and Sato C. 2012. Effect of a HomeBased Simple Yoga Program in Child-Care Workers: A Randomized Controlled Trial. The Journal of Alternative and Complementary Medicine, Volume 18, Number 8, pp. 769-776

[15] Nakagawa I. 2010.The Association of Tapping Touch, Japan.

[16] Potter and Perry.2006. Buku Ajal Fundamental Keperawatan (Edisi 4). Jakarta: EGC

[17] Banikarim C, Geffner M, Blake D and Hoppin AG, 2015. Primary Dysmenorrhea in Adolescents. UpToDate, www.uptodate.com

[18] Kolhe S and Deb S. 2011.Dysmenorrhoea; Review.Obstetrics, Gynecology and Reproductive Medicine. 21:11

[19] Perry SE, Hockenberry MJ, Lowdermilk DL and Wilson D, 2014.Maternal Child Nursing Care. St. Louis, Missouri; Elsevier Mosby

[20] Al- Kindi R and Al-Bulushi A. 2011.Prevalence and Impact of Dysmenorrhea among Omani High School Students.SQU Med J, Vol. 11, Iss. 4; 485-491

[21] Osayande AS and Mehulic S. 2014.Diagnosis and Initial Management of Dysmenorrhea.Am Fam Physician; 89 (5): 341346.

[22] American College of Obstetricians and Gynecologists (ACOG), 2015. Committe Opinion; Menstruation in Gils and Adolescents: Using the Menstrual Cycle as a Vital Sign.

[23] Dhayita P. 2011. Hubungan Stabilitas Emosi Sebelum Menstruasi Dengan Munculnya Dysmenorrhea pada Remaja di SMAN 1 Cangkringan di Wilayah Bencana Merapi. Skripsi. Universitas Gadjah Mada.

[24] Rakhshaee Z. 2011. Effect of Three Yoga Poses (Cobra, Cat and Fish Poses) in Women with Primary Dysmenorrhea: A Randomized Clinical Trial. J Pediatr Adolesc Gynecol; 24; 192 196

[25] Siahaan K, Erniati dan Maryati I. 2011. Penurunan Tingkat Dismenore pada Mahasiswi Fakultas Ilmu Keperawatan UNPAD dengan Menggunakan Yoga.FIK UNPAD.

[26] Rani K, Tiwari SC, Singh U, Agrawal GG, and Srivastava N. 2011. Six-month Trial of Yoga Nidra in Menstrual Disorder Patients: Effects on somatoform Symptoms. Ind Psychiatry J; 20(2): 97-102.

[27] Akbar HW. 2015. Pengaruh Self Tapping Terhadap Penurunan Level Nyeri Dysmenorrhea Primer pada Mahasiswi Program Studi Ilmu Keperawatan Fakultas Kedokteran Universitas Gadjah Mada. Skripsi. Universitas Gadjah Mada.

[28] Manurung MF, Utami S dan Rahmalia S. 2015. Efektifitas Yoga Terhadap Nyeri Dismenore pada Remaja.JOM Vol. 2 No. 2 